\title{
Farmers' Knowledge and Perception on Major Insect Pests of Rice and their Integrated Management in Gorkha, Nepal
}

\author{
Sudip Neupane ${ }^{1 *}$, Resham Bahadur Thapa ${ }^{2}$ and Radhika Regmi ${ }^{1}$ \\ ${ }^{1}$ Undergraduate Student, Agriculture and Forestry University, Rampur, Chitwan, \\ Nepal \\ ${ }^{2}$ Adjunct Professor, Faculty of Agriculture, Agriculture and Forestry University, \\ Rampur, Chitwan, Nepal \\ *Corresponding Author: Sudip Neupane, Undergraduate Student, Agriculture \\ and Forestry University, Rampur, Chitwan, Nepal.
}

DOI: $10.31080 / A S A G .2020 .04 .0877$
Received: July 06, 2020

Published: July 30, 2020

(C) All rights are reserved by Sudip

Neupane., et al.

\begin{abstract}
Rice (Oryza sativa L.) is the major staple crop of Nepal. Various insect pests cause high yield loss in field and storage condition. The study was carried in September-October 2018 to assess farmer's knowledge and perception on major insect pests of rice and their integrated management in Gorkha, Nepal. Respondents were selected randomly from among the study area. 120 samples were taken from 750 sampling population. Household survey was used to collect information by using a semi-structured questionnaire. The collected data were processed and analyzed by using MS-Excel and SPSS. The study revealed that rice gundhi bug, yellow stem borer and grasshopper were the major rice field pest while rice weevil and rice Angoumois moth was the major storage pest of rice in the study area. Biological practices were the least adopted practice. Use of resistant variety, use of well decomposed fertilizer, crop rotation, adjustment of planting date were the least adopted cultural practices while use of traps, rouging and clipping were the least adopted mechanical practice. All of the respondents were found to use chemical method without using all the protective wearing and safety measures. Only, few respondents had the knowledge of IPM and attended training on IPM.
\end{abstract}

Keywords: Insect Pest; IPM; Perception; Pesticide and Socio-demographics

\section{Introduction}

Agriculture is the backbone of Nepalese economy contributing $28.89 \%$ of its GDP [1]. Rice is the largest crop industry of South Asia including Nepal, playing significant role in economic and agricultural development [2]. It ranks first among the cereals in terms of area and production [3]. It alone supplies $40 \%$ of the food calorie intake and contributes nearly $20 \%$ to the AGDP and $7 \%$ to GDP [4].

Gorkha has managed only a productivity of rice of $2.83 \mathrm{MT} /$ ha [5] which is lower than that of national average productivity and far behind the potential productivity at field condition which may not be sufficient for aggrandizing population. The productivity of rice has been decreased from $3.23 \mathrm{t} /$ ha to $2.83 \mathrm{t} /$ ha from 2073 to 2074 B.S [5]. This huge gap in the attainable yield and actual yield at field and decreased trend of productivity may be the result of non-crop factors such as insect, pests, diseases, weed and other en- vironmental stresses. Insect pests constitute one of the major yield reducing factors in rice production. Further, there has been huge storage loss due to the inefficient store house and severe storage pest attack. Annual crop loss due to insect and vertebrate pests is estimated at about $25 \%$ to $38 \%$ [6]. Insect pests not only reduce the yield but also increase the production and storage cost causing both quantitative and qualitative losses.

Further, the preference of farmers towards susceptible variety, high use of chemical fertilizers, use of impure seeds, unhealthy cultivation practices has added fuel for the growth and development of rice pests such as yellow steam borer, rice gundhi bug, brown plant hopper and grasshopper causing devastating yield loss in rice. Similarly, farmers of this region are unaware about the appropriate management practices to control these insect pests and thus are using chemical pesticides haphazardly. The random use of chemical pesticides has killed beneficial insects too which the 
farmers exactly are unknown of. Thus insect pests have created both economic as well as ecological problems in this region

The current sluggish growth rate in yield can only be accelerated by using stress tolerant activities like sound Integrated Pest Management (IPM) practices that helps to create food security by increasing the productivity of rice [7]. It is the central idea of this research. This research is an attempt to picturize the knowledge level of farmer regarding the insect pests of rice and their management practices which would be helpful in finding out the lags and intervention points for reducing the huge yield loss due to insect pests. It would also be helpful in the identification of major and minor insect pests causing high yield loss in field and storage condition. Sound pest management practices adopted by the farmers can be promoted and the wrong practices could be eradicated by the study of prevailing practices. The extent of use of chemical pesticides in the study site could be known by the help of this research which could be the baseline for formulating organic agriculture promotion programs. It could thus be helpful for the policy makers and stake holders for formulating integrated pest management trainings and programs based on farmer's knowledge and perception. Further, it may also be helpful for finding out the research topic of establishing eco-friendly and economic management of insect pests of rice specific to this region.

\section{Objectives of the Study}

Broad objective

To assess the farmer's knowledge and perception on insect pests of rice and their management in the study area.

Specific objectives

- To identify the major insect pests of rice field and storage.

- To find out the adoption status of IPM practices in rice field and storage.

- To identify the extent of chemical pesticide use in rice field and storage.

\section{Materials and Methods}

Site of the study

Gorkha is one of the hilly district of western region lying between $28^{\circ} 28^{\prime} 35.04^{\prime \prime} \mathrm{N}$ latitude and $84^{\circ} 41^{\prime} 23.28^{\prime \prime} \mathrm{E}$ longitude. The district is $228 \mathrm{~m}$ to $8,163 \mathrm{~m}$ above mean sea level. It is characterized by maximum average temperature of $32.7^{\circ} \mathrm{C}$ and minimum average temperature of $4.4^{\circ} \mathrm{C}$ with an average annual rainfall of $1127 \mathrm{~mm}$. It holds $47.7 \%$ of cultivable land and $46.67 \%$ cultivated land of the total area of 3,61,000ha [5]. With 2,32,828 numbers of agriculture dependent population, the major crops grown are rice, wheat, maize, barley, lentil, chick pea, pea, black gram, pigeon pea, mustard, linseed, sunflower and ground nut. Rice dominates the cultivated area and production with 76,840 ha and 2,38,958 MT respectively [5].

\section{Selection of the study area}

The study was conducted in major rice growing region of the district that is one municipality and two rural municipality namely Palungtar Municipality, Ajirkot Rural Municipality and Siranchowk Rural Municipality respectively. These areas were purposively selected for the study.

\section{Sampling procedure and sample size}

Commercial Rice growers having more than 0.7 ha of rice cultivation area and members of three farmers' group of study area were the target population for the study. For this, DADO profile report and farmers' group report were analyzed and listed. Among the 750 farmers meeting above two criteria, 120 households were selected based on simple random sampling. For this, 50 households from Palungtar municipality, 35 from Ajirkot and 35 from Siranchowk rural municipality were selected based on rice farmers' distribution in study area. In order to avoid the biasness in the selection of the sample, a simple random sampling technique was adopted as this provides an equal chance for a selection of the elements from the sampling frame [8].

\section{Instrument for data collection}

The data collected for this study were obtained from primary and secondary sources. Primary data was collected from the field survey through the administration of pre tested semi-structured questionnaire which was used to solicit information from the respondents on issues related to objectives of the study.

Secondary data were collected from the various sources. District annual report, district profile, annual progress report and statistic book of DADO, Gorkha, rice profile book of DADO, various report from Ministry of Agriculture Development (MoAD), Central Bureau of Statistics [9], cooperatives, bulletins, books, publications from different governmental and non-governmental organizations, journals, proceedings of various NGOs and INGOs were the sources of secondary information for the study.

Data analysis

Quantitative and qualitative data obtained from the survey was analyzed and interpreted by using SPSS and MS-excel. The results were presented using descriptive tools like mean, standard deviation, frequency, percentage, bar diagrams and pie charts. Indexing was used in the ranking of important insect pests of rice. 


\section{Results and Discussion}

Socio-demographic characteristics of the respondents

\begin{tabular}{|c|c|c|c|}
\hline Variables & Frequency & Percent & Mean \\
\hline \multicolumn{4}{|l|}{ Age (years) } \\
\hline Less than 30 & 12 & 10 & \multirow{5}{*}{38.4} \\
\hline $30-40$ & 60 & 50 & \\
\hline $41-50$ & 30 & 25 & \\
\hline $51-60$ & 12 & 10 & \\
\hline More than 60 & 6 & 5 & \\
\hline \multicolumn{4}{|l|}{ Gender } \\
\hline Male & 102 & 85 & \\
\hline Female & 18 & 15 & \\
\hline \multicolumn{4}{|l|}{ Education level } \\
\hline Illiterate & 9 & 7.5 & \\
\hline Primary level & 18 & 15 & \\
\hline Secondary level & 48 & 40 & \\
\hline Higher secondary level & 36 & 30 & \\
\hline University level & 9 & 7.5 & \\
\hline \multicolumn{4}{|c|}{ Farming experiences in yrs. } \\
\hline Less than 10 & 12 & 10 & \multirow{5}{*}{18.49} \\
\hline 10 to 15 & 24 & 20 & \\
\hline 15 to 20 & 42 & 35 & \\
\hline 20 to 25 & 18 & 15 & \\
\hline More than 25 & 24 & 20 & \\
\hline \multicolumn{4}{|l|}{ Major occupation } \\
\hline Agriculture & 72 & 60 & \\
\hline Trade & 12 & 10 & \\
\hline Service & 24 & 20 & \\
\hline Others & 12 & 10 & \\
\hline \multicolumn{3}{|l|}{ Farm size in ha } & \multirow[b]{4}{*}{1.54} \\
\hline Greater than 2 & 42 & 35 & \\
\hline 1 to 2 & 54 & 45 & \\
\hline 0.7 to 1 & 24 & 20 & \\
\hline
\end{tabular}

Table 1: Socio-demographic characteristics of respondent rice farmers in study area, 2018.

Total number of rice farmers under survey is 120 for all variables.

Results presented in table 1 illustrate the socio-economic characteristics of rice farmers in Gorkha, Nepal. The results showed that the mean age of respondents was 38.4 years. The implication is that the rice farmers in the study area are fairly young. The mean age of farmers in Nepal is usually between $43-47$ years [10]. As revealed by table 1 , the majority $(85 \%)$ of the farmers were male. This implies that rice farming business is male dominated in the study area. This may be due to the high degree of human energy and physical exertion associated with farming activities, as it is evident from significantly low frequency of involvement of women in rice cultivation.
Information furnished in table 1 also revealed that the majority $(77.5 \%)$ had attended secondary level or more education. This implies that rice farmers in the study area are educated and could be trusted to adopt any innovation that could enhance rice farming practices. Okunlola [11] stated that educational level is one of the factors that influence adoption of new technology by farmers. The majority (35\%) of respondents, had between 15 - 20 years farming experience. The mean farming experience of respondents was 18.49 years. Of the 120 respondents, major occupation of the respondents of the study site was agriculture (60\%). The average landholding of the respondents was 1.74 hectares which was higher than the national average ( 0.68 hectare) [10]. Similarly, the average rice growing area was 1.54 hectare in the study area.

Farmers' knowledge and perception on rice insect pests Major rice insect pests of the study area

\begin{tabular}{|l|c|c|c|}
\hline \multicolumn{1}{|c|}{ Mode of damage } & Insect & Index & Rank \\
\hline \multirow{3}{*}{ Leaf damaging insect } & Rice grasshopper & 0.739 & III \\
\cline { 2 - 4 } & Rice leaf folder & 0.607 & V \\
\cline { 2 - 4 } & Rice hispa & 0.527 & VI \\
\cline { 2 - 4 } & Army worm & 0.327 & VII \\
\hline Sap sucker & Brown plant hopper & 0.619 & IV \\
\cline { 2 - 4 } & Green plant hopper & 0.261 & VIII \\
\hline \multirow{2}{*}{$\begin{array}{l}\text { Stem/heart damaging } \\
\text { insect }\end{array}$} & Yellow stem borer & 0.881 & II \\
\hline Root feeding insect & Mole cricket & 0.123 & IX \\
\hline Grain damaging insect & Gundhi bug & 0.954 & I \\
\hline
\end{tabular}

Table 2: Ranking of rice field insect pests by respondents in study area (2018).

When asked to rank rice insect pests based on their importance, respondents ranked Gundhi bug (grain damaging insect) as the first and Yellow stem borer (stem/heart damaging insect) as the second most detrimental insect pests on rice field as shown in table 2 .

\section{Major storage insect pests of rice}

Figure 1 shows that majority of the respondents (45\%) perceived Rice weevil as the major storage pest of rice while $28.3 \%$ perceived Angoumois moth as the major storage pest. However, $26.7 \%$ of the respondents perceived both of these insects as major storage insect pests of rice.

Adoption status of integrated management of rice insect pest

From table 3, it was observed from this research that almost all the respondents adopted the cultural practices like deep tillage (98.3\%) and flooding (96.7\%). The other cultural practices mostly 


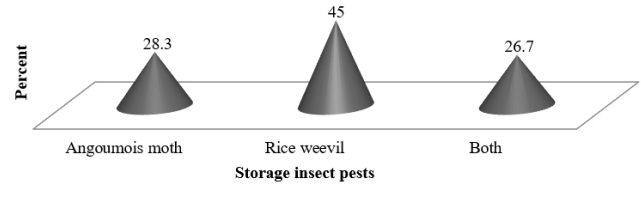

Figure 1: Major storage insect pests of rice in study area (2018).

\begin{tabular}{|l|c|c|}
\hline \multicolumn{1}{|c|}{ Various practices } & Yes & No \\
\hline Cultural practices & & \\
\hline $\begin{array}{l}\text { Field sanitation/Removal of crop } \\
\text { residue }\end{array}$ & $98(81.7)$ & $22(18.3)$ \\
\hline Deep tillage & $118(98.3)$ & $2(1.7)$ \\
\hline Use of well decomposed FYM & $36(30.0)$ & $84(70.0)$ \\
\hline Adjust planting date & $42(35.0)$ & $78(65.0)$ \\
\hline Use of resistant variety & $32(26.7)$ & $88(73.3)$ \\
\hline Seed treatment & $40(33.3)$ & $80(66.7)$ \\
\hline Adjust spacing & $50(41.7)$ & $70(58.3)$ \\
\hline Recommended seed rate & $60(50)$ & $60(50)$ \\
\hline Recommended dose of fertilizer & $64(53.3)$ & $56(46.7)$ \\
\hline Flooding & $116(96.7)$ & $4(3.3)$ \\
\hline Alternate Wetting and Drying & $46(38.3)$ & $74(67.7)$ \\
\hline Stubble burning & $96(80.0)$ & $24(20.0)$ \\
\hline Crop rotation & $38(31.7)$ & $82(68.3)$ \\
\hline Mechanical practices & & \\
\hline Handpicking & $52(43.3)$ & $68(56.7)$ \\
\hline Shaking & $60(50.0)$ & $60(50.0)$ \\
\hline Rouging & $36(30.0)$ & $84(70.0)$ \\
\hline Clipping & $38(31.7)$ & $82(68.3)$ \\
\hline Use of traps & $8(6.7)$ & $112(93.3)$ \\
\hline Winnowing & $118(98.3)$ & $2(1.7)$ \\
\hline Physical practices & $110(91.7)$ & $10(8.3)$ \\
\hline Sun dry & $52(43.3)$ & $68(56.7)$ \\
\hline Moisture maintenance & $20(16.7)$ & $100(83.3)$ \\
\hline Biological practices & $8(6.7)$ & $112(93.3)$ \\
\hline Bio-pesticides & & \\
\hline Conservation of natural enemies & \\
\hline
\end{tabular}

Table 3: Adoption status of various practices to control rice insect pests in study area (2018).

Figures in parenthesis indicate percentage. followed were field sanitation (81.7\%), stubble burning (80\%). Field sanitation is a primary cultural practice that helps to reduce the chance of infestation of majority of insect pests in the field [12]. Similarly, mostly used mechanical practice to control rice insect pest was winnowing (98.3\%) which is used to control storage rice insect pests. Likewise, some physical methods include sun drying and different measures of moisture maintenance to control storage insect pests of rice. Also, very few (6.7\%) of the respondents conserved natural enemies and only $16.7 \%$ respondents used biopesticides for insect pest control. It was found from the research that almost all the people are unknown of the biological control method of rice insect pest control. The other reason for the low use of biological method is due to exorbitant price of bio-pesticides.

Knowledge and perception on chemical method Frequency of application

\begin{tabular}{|l|c|c|}
\hline \multicolumn{1}{|c|}{ Pesticide application } & Frequency & Percent \\
\hline Once & 18 & 15.0 \\
\hline Twice & 28 & 23.3 \\
\hline More than twice & 46 & 38.4 \\
\hline At the time of insect attack & 28 & 23.3 \\
\hline Total & 120 & 100.0 \\
\hline
\end{tabular}

Table 4: Frequency of application of chemical pesticides in study area (2018).

The data in the table 4 reveals that most of the rice growers $(38.3 \%)$ of the study site applied pesticide more than twice a growing season and $23.3 \%$ of the respondents applied pesticides twice a season and at the time of insect pest attack. Only 15\% of the respondents applied pesticide once a rice growing season. This shows the heavy use of the pesticide in the study site.

\section{Dose of application}

It was evident from the research that majority (58.3\%) of the respondents applied pesticide randomly while $30 \%$ of the respondents applied the dose as per the suggestion of the seller (Table 5). Very few $(11.7 \%)$ respondents were followed the doses provided in the label.

\section{Protective wearing}

The research revealed that none of the applicators followed all the recommended safety measures which have shown that higher 


\begin{tabular}{|l|c|c|}
\hline \multicolumn{1}{|c|}{ Dose } & Frequency & Percentage \\
\hline As prescribed by seller & 36 & 30.0 \\
\hline As written in label & 14 & 11.7 \\
\hline Randomly & 70 & 58.3 \\
\hline Total & 120 & 100.0 \\
\hline
\end{tabular}

Table 5: Dose of pesticide application in study area (2018).

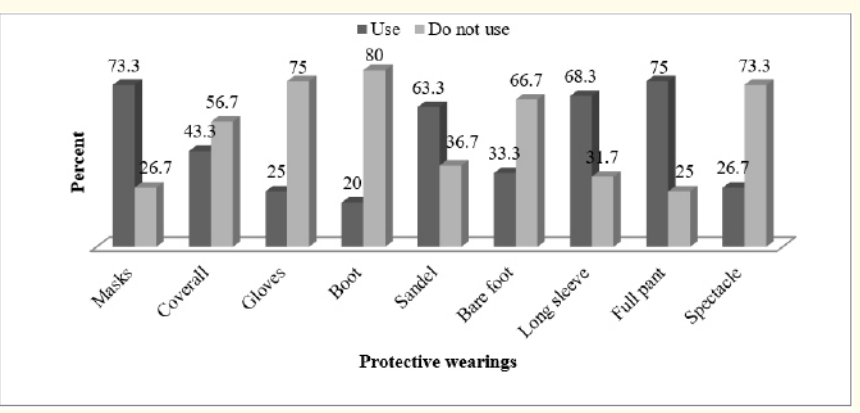

Figure 2: Use of protective wearing during pesticide spray in study area (2018).

number of farmers is exposed to the pesticide risks and health hazards. The majority of the respondents used full pant (75.0 percent), masks (73.3 percent) and sandal (63.3 percent) as protecting wearing against pesticide use while very few farmers used other protecting wearing as shown in the bar diagram.

\section{Knowledge on IPM}

Information on IPM

\begin{tabular}{|c|c|c|}
\hline Heard about IPM & Frequency & Percent \\
\hline Yes & 22 & 18.3 \\
\hline No & 98 & 81.7 \\
\hline Total & 120 & 100.0 \\
\hline
\end{tabular}

Table 6: Information of IPM in study area (2018).

Table 6 reveals that only 18.3 percent of the respondents had heard about the IPM while 81.7 percent of the respondents had not heard about IPM. This may be due to the poor extension of IPM technology in the study area.

\section{Training on IPM}

Table 7 reveals that only few (11.7 percent) respondents had attended training on IPM while rest of 88.3 percent of respondents had not got the chance of taking training on IPM.

\begin{tabular}{|c|c|c|}
\hline IPM training & Frequency & Percent \\
\hline Yes & 14 & 11.7 \\
\hline No & 106 & 88.3 \\
\hline Total & 120 & 100.0 \\
\hline
\end{tabular}

Table 7: Status of IPM training in study area (2018).

\section{Conclusion}

Rice gundhi bug, Yellow stem borer and Grasshopper are the major insect pests of rice and rice weevil and Angoumois moth are the major storage pests of rice. Among the various IPM practices, adoption of biological practices was poor. The practices like crop rotation, use of resistant variety, use of well decomposed FYM, seed treatment, use of traps, clipping were adopted by only few farmers. All the respondents used chemical method of insect pest control. Most of the farmers applied pesticide randomly without using all protective wearing and knowing all safety measures. Majority of farmers had not heard about IPM and only very few farmers had taken training on IPM.

\section{Suggestion}

For the control of rice insect pests, quality seeds should be distributed to the farmers. Location specific insect pest control research should be conducted and the effectiveness of the control measures should be promoted through FFS. Efficient extension programs should be conducted for the promotion of IPM practices in rice field and storage. Heavy use of chemical pesticide should be controlled and replaced by safe methods. Farmers should be made aware about health hazards and environmental hazards of random use of chemical pesticides through extension programs. Policies and programs aiming the reduction of use of chemical pesticides need to be formulated.

\section{Acknowledgement}

Mr. Nishan Luintel is hereby acknowledged and appreciated for his hard work and persistence during data collection stage of this study.

\section{Conflicts of Interest}

The authors declare that there is no conflict of interest regarding the publication of this paper.

\section{Bibliography}

1. MoAD. Krishi Diary. GoN, MoAD, Agriculture Information and Communication Centre, Hariharbhawan, Lalitpur (2018). 
2. Gumma MK., et al. "Temporal changes in rice-growing area and their impact on livelihood over a decade: A case study of Nepal". Agriculture, Ecosystems and Environment 142.3-4 (2011): 382-392.

3. ABPSD. Statistical Information on Nepalese Agriculture 2015/16. GoN, MoAD, Monitoring, Evaluation and Agri Statistics Section, Kathmandu (2016).

4. CDD. "Rice Varietal Mapping in Nepal: Implication for Development and Adoption". GoN, MoAD, DoA, Crop Development Directorate, Hariharbhawan, Lalitpur (2015).

5. DADO. "Annual Report and Statistical Book". District Agriculture Development Office, Gorkha (2016).

6. Lamsal HN. Bali Biruwama Lagne Kehi Mahatwopurna Rogharu ko Pahichan Tatha Bewasthapan (First). GoN, MoAD, DoA, Plant Protection Directorate, Hariharbhawan, Lalitpur (2016).

7. Pandey S., et al. "Patterns of adoption of improved rice varieties and farm-level impacts in stress-prone rainfed areas in South Asia". In Patterns of adoption of improved rice varieties and farm-level impacts in stress-prone rainfed areas in South Asia. International Rice Research Institute (2012): 1-326.

8. Scheaffer R. Elementary Survey Sampling. Massachusetts, USA: Duxbury Press (1979).

9. CBS. Nepal Living Standard Survey. Kathmandu, Nepal: National Planning Commission Secretariat, Government of Nepal (2015).

10. MoAD. Statistical Information in Nepalese Agriculture. Kathmandu, Nepal (2015).

11. Okunlola JO. "Factors influencing Adoption of Rubber Based Technologies among Small Holder Farmers in Delta state Nigeria". Journal of Food Agriculture and Environment 8.2 (2010): 391-394.

12. Neupane FP. Balibiruwaka Satru Ra Tinko Roktham (Crop pests and their management) (6th ed.). Sajha Prakashan, Pulchowk, Lalitpur (2017).

\section{Assets from publication with us}

- Prompt Acknowledgement after receiving the article

- Thorough Double blinded peer review

- Rapid Publication

- Issue of Publication Certificate

- High visibility of your Published work

Website: www.actascientific.com/

Submit Article: www.actascientific.com/submission.php Email us: editor@actascientific.com

Contact us: +919182824667 